\title{
Labour-time in the Dot.Com Bubble: Marxist Approaches
}

\author{
Frederick Harry Pitts
}

\section{Introduction}

Looking at the Dot.Com boom and bust witnessed in the United States between 1995 and 2003, this paper will give an interpretation of Marx's mature economic thought with a particular emphasis upon the role of labour-time in his wider theory of capitalist production and breakdown. It will situate this conceptual apparatus in the context of radically different conditions of work and capitalist production than those with which Marx was confronted in the writing of Capital. This will be done by building up an analysis of the position of labour-time in the creation of absolute and relative surplus-value and the determination of the make-up of the organic composition of capital with specific reference to the circumstances which saw a financial bubble develop around the so-called New Economy of fledgling tech, telecommunications, ICT and internet start-ups in the US during the late nineties and early noughties. Utilising quantitative and qualitative data including government statistics and ethnographic accounts to illustrate the operation of Marxian analytical categories, the paper will assess the usefulness of Marx's conceptualization of labour-time and crisis to an analysis of the US economy over the period described, and gauge to what extent it requires recalibration to adequately grasp the changes in the organization of capitalist production identified in the research.

Whilst much of the evidence provided will reveal that Marx's theorization is still of considerable relevance to contemporary capitalism, there nonetheless remain certain aspects of the New Economy that his economic work are at a loss to comprehend. On the one hand, the Marxist tradition is still a valuable framework through which to view the global economy. Yet, on the other, contemporary capitalism possesses many qualities that require that tradition to be updated in order to help us understand and interpret changes in the way in which wealth is generated. Chief among these is the increasingly immeasurable nature of labour-time in the context of primarily intangible and immaterial processes of production. It is argued that autonomist Marxism presents a strong example of the way in which Marx's original categorizations can be reconfigured to form a theoretical perspective adequate to these new circumstances, which can be combined critically and fruitfully with the earlier theoretical paradigm to illuminate contemporary conditions of labour and capitalism.

The Dot.Com boom and bust which afflicted the United States between 1995 and 2003 is a good arena in which to have this discussion, presenting as it does an example of a capitalist crisis based upon a demonstrable low rate of profit, the chief feature of Marx's conceptualisation of breakdown, but displaying at the same time a number of distinct characteristics in the realm of production which suggest that the easy generalisations around working time that one can extrapolate from Marx need clarification and recalibration in adjustment to the historical conditions of the period. The article suggests that autonomist Marxism may provide such a necessary recalibration, whilst simultaneously retaining in a clarified and enhanced form many of Marx's original insights.

\section{Background}

The Dot.Com boom and bust refers to the series of events whereby the US economy witnessed a financial 
expansion in the early nineties based up growth, investment and productivity in one area in particular, the so-called 'New Economy' of high-tech and internet-oriented ICT and telecommunications start-ups that arose at that time. Their market valuations supported the US economy even as it fought against a persistently low rate of profit in the chief economic activity zone of manufacturing. Indeed, equity prices soared even when established on a foundation of low rates of profitability in the non-manufacturing sector, of which many of the companies the boom was based on were part. However, the New Economy, for a time at least, exerted an upwards pull on the fortunes of the US economy and remedied the ills of a falling rate of profit. In this article we will seek to ascertain to what extent this was due to changes in the way wealth was generated at the coalface, in the realm of production where the new kinds of companies associated with boom displayed a significant amount of specificity and novelty in the way they organised the temporal patterns of the workplace, among a more general shift in the culture of work.

One of the primary factors distinguishing New Economy production is its reliance on radically recalibrated structures of the working day. An ethnographic account of an archetypal New Economy firm specialising in ICT business services by Andrew Ross provides an exemplary picture of the workplace culture of the time (2003). Some of the features identified by Ross include: a pernicious informality that channels ever-increasingly the subjectivity of the worker into the job, creating a grey area into which work and leisure collapse; an environment in which developing new skills and social networks and solving problems in one's spare time becomes part of the substantive work task; and a significant degree of employee investment and involvement in the company and its ethos, inducing the worker to give swathes of their own time to the business in the name of a higher and more personal ideal. As we shall see, the theorisation of such labour, whereby communicative, emotional and cognitive capabilities are deeply implicated in the work itself, is one of the attributes of autonomist Marxism that render it well-placed to update Marx's initial conceptualisation of labour-time and the role it plays in remedying capitalist crises.

The very aspects of these enterprises that provided the novel and investment-worthy status that served to propel them into the driving seat of the US economy are precisely those which made the work involved so deleterious to perform. The internet itself can be seen as a prime mover in this. Far from the new technology upon which the bubble was based clearing the ground for a reduction in working hours, rather the 'finite workday' was 'obliterated' by the constant contact to information networks offered by the internet, leading to eighty-hour workweeks in some of the New Economy businesses Ross reports upon (2003, pp. 44, 51).

In seeking to construct an account of the Dot.Com boom and bust from its roots in the realm of production, the significant characteristics of working patterns expressed in Ross's research display the importance that labourtime possesses as the theoretical pivot upon which any analysis is to be advanced. In this chapter we will see that Marx's theorization of labour-time is an effective tool for viewing the changes that took place in production and the rate of profit in the US economy during the period in question. However, we will conclude that there is a general inability to grasp the way in which the boundaries between work and non-work time have become ever-increasingly indistinct, and as such render inadequate traditional quantitative measures of labour-time. This will bring us to the insights provided by the autonomists.

\section{Surplus-value and Exploitation}

It is necessary to begin at the most basic components of Marx's theory of labour-time. For Marx, the production of commodities is divided up into two parts: necessary labour and surplus labour. Translated into time, the first portion has two determinations: the amount of time taken to produce the commodity demanded for sale by the capitalist; and the amount of time the worker takes to produce the commodity in order to reproduce his labourpower with the consumption of equivalent commodities through the provision of a wage. Whereas the necessary labour-time is that part of the working day where the labourer works 'for himself', what Marx calls surplus labourtime is time spent working for the capitalist. The labour-time spent working over and above that taken to ensure a wage and the reproduction of the worker's labour-power is spent contributing to the production of surplus-value, that part of the value generated left over when the worker's recompense and other associated expenses are taken into account. The urge to expand this quantity provokes the capitalist to extend this portion of the working day as far as possible. As such, the rate of surplus-value is also the rate of exploitation: surplus labour divided by necessary labour (Marx, 1990, pp. 324-6) Such an approach demonstrates the centrality of labour-time to Marx's analysis, whereby the actual degree of exploitation, one human by another, is gauged purely by the amount of time worked for free by the 
worker for the capitalist.

The rates of surplus-value and exploitation have a tendency to rise as the capitalist will seek to extract as much labour-time as possible from the labour-power he has purchased. In this way, the capitalist is simply attempting to gain as much use as he can from the commodity he has purchased in the marketplace. The contract of employment signed, the capitalist possesses full discretion over the way in which the commodity at his disposal is used. For the capitalist, 'moments are the elements of profit', and with a watchful eye on the clock, times extraneous to the labour process are carefully cropped, with the beginnings, ends and break-times that circumscribe and permeate the working day decomposing into an amorphous mass of time made pliable to the purposes of the production of surplus-value. Such is the capitalist's 'right' as a buyer (ibid., pp. 342-44). Capital holds the tendency to exceed all limits and physical bounds upon the working day, attempting always the absorption of every second of the worker's disposable time. As such, Marx signifies here that 'to appropriate labour during all the 24 hours of the day is the inherent tendency of capitalist production' (ibid., p. 367).

As the account provided by Ross testifies, labour-time in Dot.Com enterprises was extended in such a way, occupying every pore of existence. Average working hours increased throughout the decade, in line with the rate of surplus-value, dropping off as the economy stagnated, as evinced by Figure 1 (see appendix for details of sources and calculations). Our calculation of the rate of surplus-value is profits divided by employee compensation.[1]

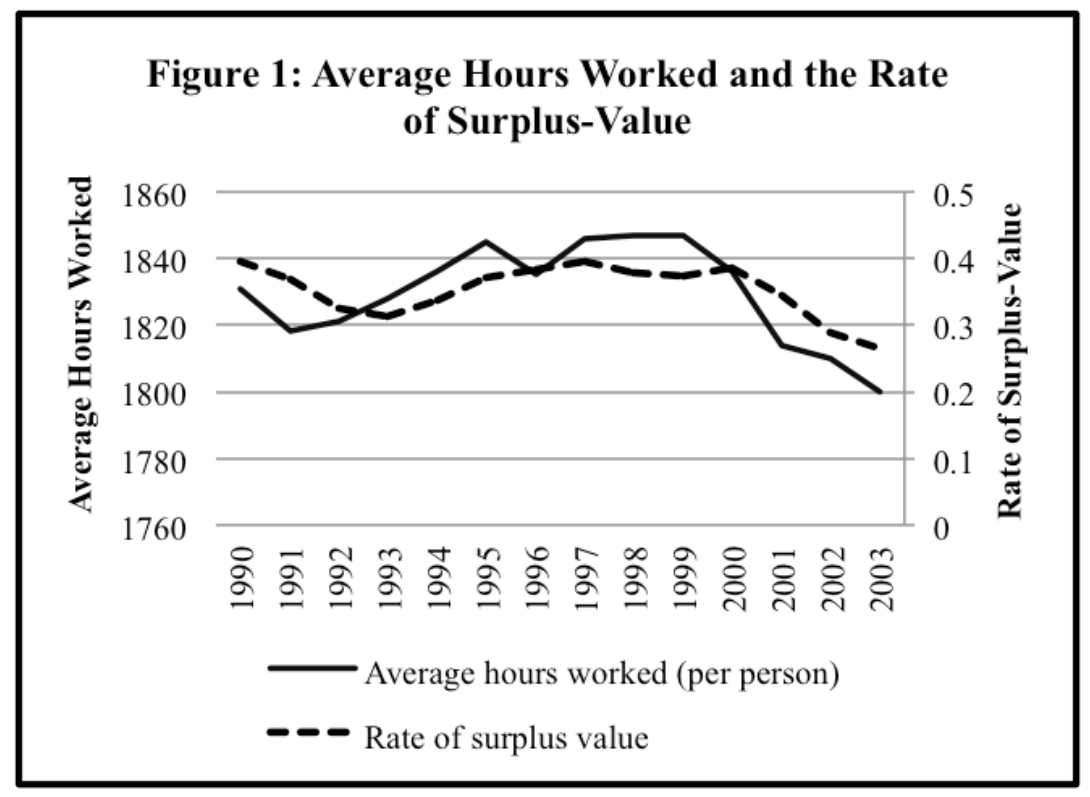

Figure 1

This data will be significant when we consider why capitalists might choose to prolong the working day depending on prevailing economic circumstances. For now, it is sufficient to say that Figure 1 displays the importance of labourtime to capitalist economic fortunes, a rise in the average hours worked coinciding with prosperity and a fall with times of relative hardship. The average amount of hours worked also neatly correlates with the rate of surplus-value.

\section{Absolute and Relative Surplus-value}

Thus far we have explored what Marx calls the production of absolute surplus-value. This is where surplusvalue is accrued through the extension of the working day. In terms of altering the make-up of the working day in the pursuit of surplus-value, the other means that the capitalist has at his disposal is to intensify rather than extend the working day, recalibrating its internal composition rather than its external limits. This is known as the production of relative surplus-value. The principal process by which this is effected, and one very much in evidence in the conditions surrounding the Dot.Com bubble, is the influx of technology into production. 
In place of the constant necessary basis of the working day that we assumed in our previous discussion of labourtime, relative surplus-value is structured around 'the curtailment of necessary labour-time, and the corresponding alteration in the respective lengths of the two components of the working day' (ibid., pp. 429-432). With relative surplus-value, rather than the absolute length of the working day being the moving participle on which production depends, that division which separates the working day into necessary and surplus portions becomes the territory in which capital exerts control over the time of workers.

The primary aim of capital can be seen to obtain less to a downward push on the total labour-time demanded of the worker, than to a downward push on the socially necessary labour-time in which the worker labours for himself and thus a corresponding rise in the amount of surplus labour-time devoted only to production for the benefit of the capitalist. Therein we are presented the way in which the production of relative surplus-value exerts as much influence upon the capitalist manipulation of the worker's time as does that of absolute surplus-value. We can best appreciate the difference when it becomes a question of how to increase surplus-value in the very last instance; when certain givens obstruct capital's path. With the working day given, the relative restructuring of the necessary/surplus partition is the only option capital has recourse to. With productivity or intensity given, capital only has recourse to the extension of the working day. As David Harvey writes, quoting Marx, [t] he difference is only one of capitalist strategy that "makes itself felt whenever there is a question of raising the rate of surplus-value" (Harvey 2010, p. 237).

It is such questions of capitalist strategy with which we are preoccupied here. Where relative surplus-value cannot extend its domain any further for its downward influence on profitability, it might be suggested that capital can only satiate its need for surplus-value through recourse to methods of producing absolute surplus-value, namely, the lengthening of the working day. The arena in which such questions of capitalist strategy can be put is that in which they are posed with most urgency, in situations of capitalist crisis such as that of the Dot.Com crash. The key concepts in Marx's theory of crisis are the organic composition of capital and the tendency of the rate of profit to fall. We will discuss these with reference to the conditions of crisis as they arose in the Dot.Com boom and bust.

\section{Crisis}

The beginning of the Dot.Com boom can be attributed to the initial public offering (IPO) of stocks and shares by Netscape (Brenner 2002, p. 142). This set off an equity price bubble around firms similarly situated in the technology, media and telecommunications (TMT) sector. The new pre-eminence of non-manufacturing enterprises in the fortunes of the US economy should be seen against the background of a falling profit rate in the manufacturing sector after 1995. The ascendency of Dot.Com stocks and shares represented a boon to the ailing state of the traditional pillars of the US economy. However, the rise in equity prices around the TMT sector struggled against a similarly low underlying profit rate, with the valuations of stocks and shares separated from tangible measures of success (ibid., pp. 138-9). Telecommunications, despite in spring 2000 producing less than three per cent of GDP, had stocks and shares valued at $\$ 2.7$ trillion, representing some fifteen per cent of the value of all non-financial entities (ibid., p. 292). The profits which ran parallel to these valuations offered little in the way of comparison. The contradictions presented by the combination of low profitability and high equity prices could hold no longer, with a crisis which began in telecommunications spreading to all high-technology firms and beyond, encapsulating e-commerce, internet content, infrastructure, connection services and a whole host of other ICT and new media-oriented functions. By winter 2001, there had been a 60\% fall in the NASDAQ Index, where many of the internet and technology companies which had driven the boom were listed. Nearly 5,000 internet-related companies closed or were acquired at a loss in the first quarter of 2000 (ibid., pp. 248-9).

It is the position of this paper that the eventual crisis that unfolded from these boom conditions, and which erupted in 2000-2001, could plausibly be seen in the context of this persistent low profitability across sectors and the possible attempts at remedying this low rate of profit represented in the fledgling work practices and industrial cultures of the New Economy. The warped valuations of Dot.Com enterprises that arose in spite of this low profitability, it may be argued, is just one expression of capital's attempts to mediate and remedy the underlying problems that afflicted the economic situation. In this article, our focus is upon how the management of time within New Economy companies presents an interesting and useful prism through which to see the ways capitalism seeks to adapt and react to obstacles and paralyses that afflict its reproduction. 


\section{The Organic Composition of Capital}

Marx's treatment of the interrelationship between trends in the organisation of labour and the manifestation or mediation of crises relies upon a series of concepts: constant and variable capital, the organic composition of capital and the tendency for the rate of profit to fall. For Marx, the inputs into the labour process are divided into constant and variable capital. Constant capital represents all means of production, machinery and raw materials. Variable capital is the human living labour which engages the elements of the former category. For Marx, the ratio between these two elements is of paramount importance in analysing capitalist production. This ratio Marx labelled the organic composition of capital (Marx, 1990, p. 762). The organic composition of capital (OCC), for Marx, presents the moving contradiction in his analyses of capitalist crisis. The increased productivity of capitalist production inevitably leads to the influx of new and greater means of production into the labour process. This drive toward improved efficiency necessarily results in the expulsion of labourers from employment, or in workers assuming control individually of an ever-expanding amount of technology. Either way, the proportion of constant capital to variable can be seen to rise, as either the amount of workers or the amount of hours worked decrease. For Marx, this proportional change can impact negatively upon the rate of profit, depriving as it does capital of the human labour to which it owes the creation of specific use-values for sale on the market as commodities (ibid., p. 318).

Thus, when we speak of the rising organic composition of capital, we refer to the increase in constant capital (raw materials, machinery, means of production) against variable capital (living labour) as a proportion of the total capital submitted to the production process. Brenner asserts that the US economy was plagued by over-capacity through the course of the Dot.Com boom. This over-capacity essentially represents having at one's disposal means of production into which no labour can be absorbed; in other words, too high a proportion of constant capital (2002, p. 46). In figure 2 we have calculated the OCC using proxies. For constant capital, we have used the capital stock, which is the total fixed capital and assets at the disposal of industry, and for variable capital, we have used employee compensation (see appendix for sources).

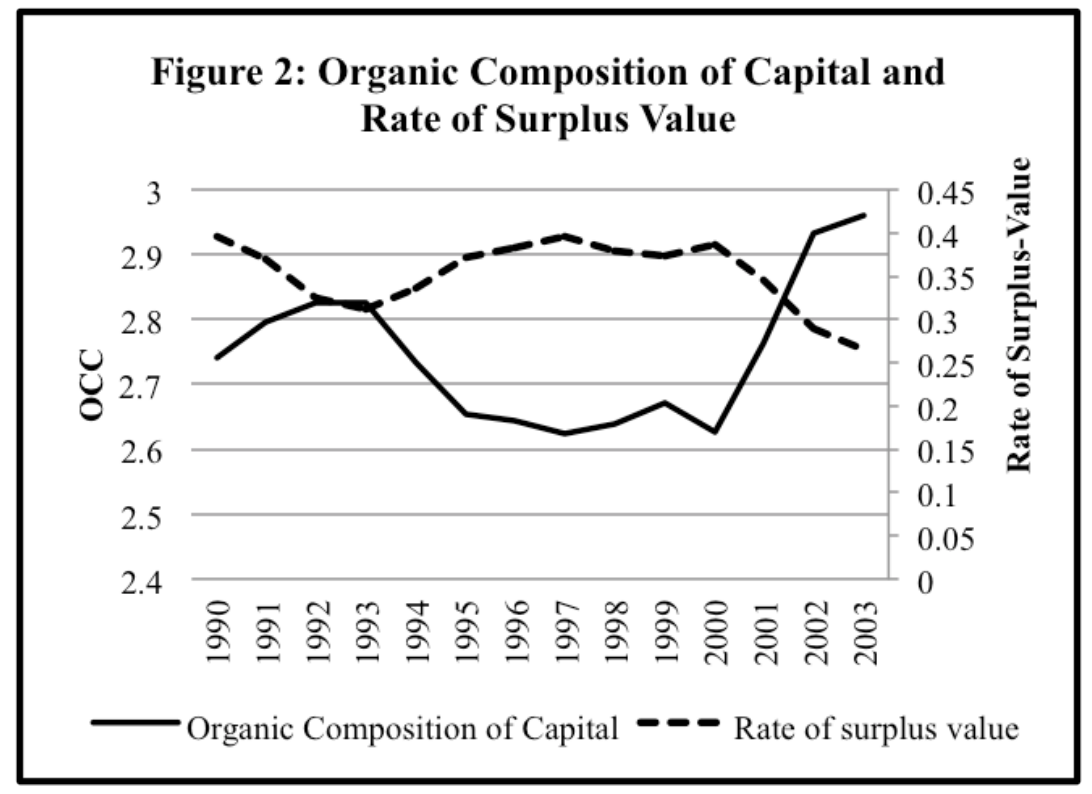

Figure 2

Figure 2 illustrates that there is an inverse correlation between the rate of surplus-value and the OCC. When the rate of surplus-value is lower, the OCC is higher. This is arguably because the increase in the amount of constant capital in the production process proportionally displaces the human labour-time represented in variable capital, decreasing the rate of surplus-value. The influx of high-technology means of production into most sectors of industry during the Dot.Com decade can be seen to have exerted great influence on these categories; the degree to which constant capital outweighed variable is exhibited, as we have noted, in the over-capacity that the system was 
subject to.

With these insights in mind, it is not hard to see the potential contradiction in the rising OCC. The increase in the 'social productivity of labour' through the influx of new technology at once promises the opening of the full potential of capitalist production whilst simultaneously belying the destruction of the very foundation upon which it is established and maintained. The devaluation of labour-power, and the diminishing of variable capital in the OCC starve capital of the one thing upon which it thrives: human labour-time. Constant capital, despite its role in productive growth, bestows no new value through the means of production. Human labour plays an ever lesser role. Whilst this can be masked to an extent by an ever-increasing mass of surplus-value and profit, these false glories only serve to obscure an underlying tendency towards falling rates of surplus-value (and, of course, more immediately, rates of exploitation) and profit (Marx, 1981, p. 324).

\section{| Rate of Profit}

The falling rate of profit is for Marx a tendency, rather than an iron law. It is contingent upon factors which may influence its operation and remedy its negative ramifications. In the OCC, as the total capital is forced upwards by the rise in the constant element, the proportion of the total capital represented in variable capital decreases to the detriment of the rate of profit. The unchanging rate of surplus-value in such equations is mirrored in the stagnation or regression of the rate of exploitation. However, this drop in rates of exploitation (and, hence, surplus-value) can be staved off to a certain extent by means of a recourse to absolute surplus-value. An increase in absolute surplusvalue is necessary to preserve the rate of profit in the face of a rising total capital spurred on by the increase in the constant component.

Like Marx, Brenner emphasizes that 'capitalism tends to develop the productive forces to an unprecedented degree, and that it tends to do so in a destructive, because unplanned and competitive, manner' (1998, p. 23). Brenner presents a spiral of contradictions which ultimately, and usefully, provide grounds for comparison with Marx's theory by sharing the same basic premise: that the rise in productivity sows the seeds for the fall in profitability. As Brenner writes, in the mid-nineties 'the main forces shaping the economy of both the boom of 1995-2000 and the slowdown of 2000-03 were unleashed' (2004, p. 59).

Brenner's conceptualisation of the Dot.Com boom and bust locates the decline of profitability with which the bubble struggled in two, overarching factors. Firstly, productivity is increased by new cheaper and more effective methods, which neglect the 'requirements for realization' of existing investments in plant and equipment. Secondly, this results in falling profitability because it creates 'reduced prices in the face of downwardly inflexible costs.' Due to the 'resulting consolidation of over-capacity and over-production' (and the associated reduced profitability), investment, output and wages will decline, leading to subsequent reductions in productivity and effective demand. These conditions add further downward pressure on profitability, constituting a vicious cycle. Therefore, perhaps the key contradiction for Brenner is that ' $[\mathrm{t}]$ he same cost-cutting by firms which creates the potential for aggregate profitability to rise creates the potential for aggregate profitability to fall, leading to macroeconomic difficulties' (1998, p. 24). This contradiction is essentially that proposed by Marx.

In an example of how a Marxian analysis can be applied to concrete examples of economic history, the mid nineties present an interesting case. Brenner juxtaposes the fall in profitability in manufacturing over the period 19961997 with the increase in profitability that occurred in non-manufacturing. What interests us about the latter is the way in which the rise in the rate of profit occurred alongside lower productivity when compared with manufacturing $(2.35 \%)$, higher wages growth than manufacturing $(3.2 \%)$ and higher unit labour costs $(0.85 \%)$ than manufacturing. The figures for the manufacturing sector were 3.2\%, 1.7\% and -1.5\% respectively (for 1996 and 1997) (Brenner 2002, pp. 135-7). What we see here is a rise in the profitability of those sectors with an OCC consisting of more variable capital and less constant capital, the variable capital represented in the higher wages and unit labour costs, and the reduced constant element in the lower productivity.

As figure 3 reveals, the tendency identified by Marx, of a rising OCC driving down the rate of profit is affirmed by the evidence available to us from the US economy between 1990 and 2003, with the rate of profit calculated as non-financial corporate profits and net interest divided by capital stock (see appendix for sources). As we have 
previously identified, this rising OCC was achieved at the expense of the rate of surplus-value, with human labourtime displaced by an influx of new means of production into the labour process. Despite increases in working hours, it was still not enough to imbalance the proportional rise of constant capital in the ratio that determines the OCC. This can be seen to have negatively influenced the rate of profit over the period in question. It is evident, therefore, that Marx's theorization holds significant utility for an analysis of this period.

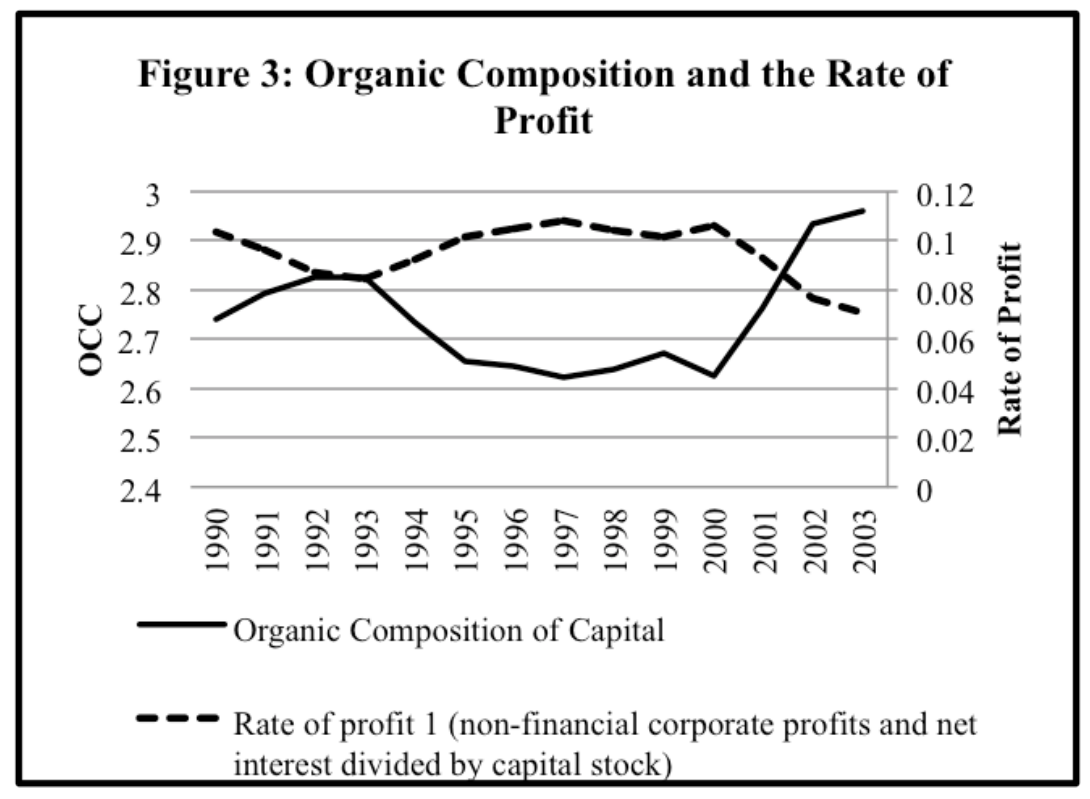

Figure 3

\section{Countervailing Tendencies}

With the decrease in profit established, Marx comes to the problem of explaining why the fall in the rate of profit is 'not greater or faster', and why it takes only the form of a tendency as opposed to a certainty. Marx suggests that '[c] ounteracting influences must be at work, checking and cancelling the effect of the general law and giving it simply the character of a tendency, which is why we have described the fall in the general rate of profit as a tendential fall' (ibid., p. 339). We will focus on one countertendency in particular: the increase in exploitation through a rise in absolute surplus-value.

Primary among Marx's list of countervailing tendencies is the 'more intense exploitation of labour'. The principal means by which capital can exploit labour further is through the prolongation of the working day. For Marx, this increases the amount of surplus labour appropriated without basically altering the ratio of the labourpower applied to the constant capital that this sets in motion, and which in point of fact rather reduces the constant capital in relative terms.' Marx writes that 'the tendency for the profit rate to be reduced, in particular, is attenuated by the increase in the rate of absolute surplus-value that stems from the prolongation of the working day [...].'

Fine and Saad-Filho (2004, p. 43) claim that absolute surplus-value is 'at any time a remedy for low profitability'. We can see evidence of the continuing relevancy of this remedy in the accounts of labour-time given earlier in the paper. The evidence presented from the research suggests that working hours did rise over this period. Figure 4 allows us to see whether or not this in any way correlated with, or possessed any determination on, the rate of profit (see appendix for data sources). As displayed, profitability does seem to follow trends in labour-time, increasing when average working hours are higher, decreasing when they are lower. This suggests that the increase in exploitation achieved through the production of absolute surplus-value via the extension of the working day may well constitute an effective and historically useful countervailing influence upon the tendency of the rate of profit to fall. 


\section{Figure 4: Rate of Profit and Average Hours Worked}

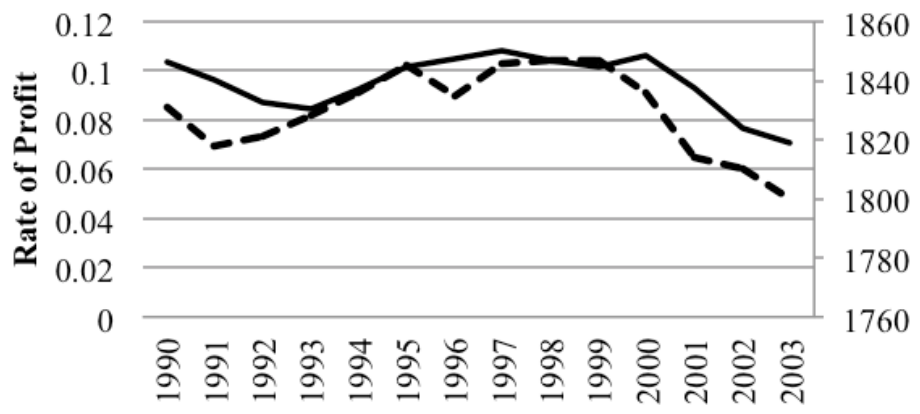

1860

1840

1820

1800

1780

1760

- Rate of profit 1 (non-financial corporate profits and net interest divided by capital stock)

- Average working hours per person

Figure 4

\section{Beyond Measure?}

However, despite this statistical confirmation, we might also reflect upon the anecdotal and ethnographic evidence found in the accounts provided earlier in the paper. Long working days were described where no clear demarcation was possible between necessary and surplus, or even paid and unpaid working time. The tendency in labour-time presented in the figures above does not seem to directly reflect those accounts of ever-increasingly longer working days, relying as it does on standard numerical and quantitative means of ascertaining work time rather than the qualitative dominance it can be seen to assume in ethnographic accounts and elsewhere. The countervailing tendency of an increase in the rate of absolute surplus-value may still be a useful way to view the responses of the capitalist organisation of work-time to a context of capitalist crisis, but new understandings forged squarely in the contemporary scene may be needed to reinforce its utility. In the remainder of the paper, we will display how the autonomists help us understand the extra labour-time expended in the New Economy as one 'beyond measure', and thus resistant to such statistical appreciations.

As we have seen in this chapter, Marx's theorization of labour-time, composition and profit does provide a good basis for understanding what took place in the US economy during the nineties and early noughties. However, if we consider the testimonies as to the structure of the Dot.Com working day, which emphasizes the increasing indistinctiveness of where the working day ends, the Marxist construct, formed in response to a set of industrial, material and physical conditions of labour that lent themselves well to measurement and estimation, may face some difficulty in examining a capitalism in which labour is broadly immaterial, the actual amount of time in which it takes place elusive, and the inputs and outputs that it consumes and creates increasingly of an intangible and transient quality. These are the limitations that form the crux of the particular research puzzle we are seeking to piece together, and which lead us to the autonomist Marxists as a means by which these gaps in Marx's economic theory can be plugged and eventually reconciled to the new conditions of production in contemporary capitalism.

\section{Autonomist Marxism}

We have seen that Marx's theorization of labour-time provides a good basis from which to extrapolate a number of insights about the economic trends of the Dot.Com boom and bust. However, in light of the ethnographic research presented at the beginning of the paper and the assessment of the distinct culture of long working hours 
that was witnessed in the New Economy enterprises at the centre of the bubble, there are ways in which Marx's conceptualization of capitalism could be bolstered by a recalibration formed in response to the new conditions of production exhibited, rather than remaining tied to the very different realities of his own time. We will see that autonomist Marxism presents a basis from which to make this theoretical leap.

\section{Immaterial Labour}

The most superficial difference between the autonomist theory of production and that of Marx may appear to be the way in which contemporary labour is presented. Indeed, in their analyses of the economy, autonomists do differ from more traditional empirical strands of Marxism in attempting to update Marxian categories such as absolute and relative surplus-value and variable and constant capital to reflect an economy reliant upon the new kinds of work exemplified in the New Economy. Key here is the theorisation of immaterial labour, 'that is, labour that produces an immaterial good, such as a service, a cultural product, knowledge or communication’ (Hardt and Negri 2001, p. 290).

Due to the fact that such 'immaterial labour' relies upon the everyday human capacity to communicate, consume, empathize, cognize, and emote, the boundaries between labour-time and non-labour-time become ever-increasingly blurred and indistinct. As Hardt and Negri vividly convey, '[w] hen production is aimed at solving a problem [...] or creating an idea or a relationship, work time tends to expand to the entire time of life. An idea or image comes to you not only in the office but also in the shower or in your dreams' (2004, pp. 111-112). In this way, the blurring of boundaries between labour-time and non-labour-time is, as Paolo Virno asserts, a symptom of the increasing similarity between human activity and labour activity (2004, pp. 102-3). Whilst such graphs as those used to illustrate Marxian categories of labour-time might be useful, they suffer for their inability to adequately reflect the seemingly immeasurable quality of the immaterial labour of the Dot.Com industry.

The autonomist theorization of time seems to suggest, when read in conjunction with the Marxist perspective expressed in the first part of this paper, that what is being posited is a return to the production of absolute surplusvalue. This suggests a shift in favour of variable capital in the OCC; however, autonomist theory mounts a radical reconceptualization of constant capital which demands a more inclusive approach. Alongside the extension of labour-time out of the 'factory walls' and into the 'immaterial basin' of society at large, autonomist theory provides further grounds for challenging and reformulating the Marxian conception of the roles of variable and constant capital in the OCC. This takes the form of a line of reasoning derived from Marx himself, yet taken much further by the autonomists. This concerns the concept of general intellect. We will first outline the concept and the role it plays in Marx's thought, followed by an examination of its centrality to the autonomist theoretical project, engaging with the ways in which the autonomist embrace of Marx's concept has been updated and reflected back upon Marx's other work in order to demand a new interpretation of the OCC.

\section{General Intellect}

In the 'Fragment on Machines' from the Grundrisse (1973), Marx states that the increase in machinery in the labour-process displaces human labour to the extent that the activity of workers is reduced to a purely supervisory or regulatory role alongside the new chief actor of the labour process, the machine, weakening the role of labourtime as the measure of human productive activity. This technological leap brings about the possibility of a social development on a massive scale, as workers, freed from physical subordination to the means of production and newly possessive of the increased 'power to enjoy' in their disposable time, avail themselves of great advances in their intellectual and cooperative capabilities. In defining the 'general intellect' so enabled, Marx makes the assertion that the capacities developed in the worker's new free time will reinsert themselves into the production process without coercion as fixed capital, incorporating the worker only at a distance, rather than as a constituent part of the capital relation (Marx 1973, pp. 705-6).

Virno's considered account of the reality of the general intellect disavows any temptation to claim that these conditions are those we are party to today. Virno draws upon Marx's developmental, tentative conception of the 
general intellect to paint a picture of the way in which increased 'freedom' from the formal infrastructure of the labour process is turned to capital's advantage as a means whereby the bond between employee and employer can be strengthened.

Virno accepts that technology, when it fails to subordinate workers ever further to its command, has opened up time in which the worker may devote his energies to other tasks. Furthermore, like Marx, Virno claims that the results of this do find their way back into the production process. However, Virno presents an account of the situation whereby the emancipatory content of the general intellect is neutered, its benefits ploughed by capital into ever-increasing control over the organization of time and the reduction of human activity to a subservient function of the imperative to produce and profit. Virno writes that ' $[\mathrm{w}]$ hat is learned, carried out and consumed in the time outside labor is then utilized in the production of commodities' (Virno 2001).

The research conducted by Ross on work in the New Economy reveals the extent to which this was the case in the Dot.Com boom; training oneself to adopt new skills demanded by ever-changing technology was estimated to occupy up to 13.5 hours of the worker's unpaid free time per week (2003, p. 93). With immaterial labour, the reappearance of the increased knowledge and intellect possessed by labourers as fixed capital (or constant capital) in the labour process does not occur. The benefits of the social development of the workforce instead reappear simply as living labour, variable capital, the human subject of exploitation at the hands of capital.

Virno emphasizes the role of communication in this subjugation of human capacities to the logic of the labour process, suggesting that ' $[\mathrm{t}]$ houghts and discourses function in themselves as productive 'machines' in contemporary labor' (Virno, 2001). Hardt (2008, p. 10) elaborates further, contending that 'our brains, linguistic facilities, and interactive skills' have assumed the position previously held by machines in the constitution of constant capital. As Virno (1996, pp. 22-3) concludes, rather than destabilizing capitalist production, the general intellect, and the organization of time around it, has in fact become 'the stabilizing component' of the capital mode of production'. From our reading of Marx, it might be suggested that this stability arises from the primacy of living labour in the labour process; whereby variable capital, the wellspring of surplus-value, is increased in proportion to constant capital by means of the extension of the working day and thus of labour-time as a factor in production. The experience of workers in the New Economy suggest that the immaterial forms of labour which autonomist analyses seek to understand terminate not in the optimistic picture provided by Marx in his Fragment on Machines but rather in the almost infinite increase in absolute surplus-value made possible by their boundary-breaching intangibility, and by which capital attempts to insulate itself from crisis and further falls in the rate of profit, as seen in the previous discussion.

\section{Linguistic Machines}

The reality of general intellect- the turning of free time and the power to enjoy towards productive ends of capitalist value- manifests itself a self-valorising, cooperative plenitude of creative activity that continues regardless of its direct organisation by capital. The most obvious example of this is that the economic boom around the internet relied upon millions of hours of unpaid labour on the part of amateur programmers and run-of-the-mill users. The attempts of capital to capture the value so produced demand us to reconceptualise the way in which the Marxian categories of variable and constant capital, and their relationship through the OCC, function in such a context.

The capacity of workers to cooperate spontaneously, outside the direct coordination of the capitalist, demands that we reconsider the category of 'variable capital' as traditionally understood when examining the autonomist reformulation of the OCC. Whereas Marx pictured the labour-process as featuring a productive cooperation between workers organized by the capitalist, Hardt and Negri (2001, p. 294) make the claim that cooperation instead becomes the self-organizing function of the workers themselves. This cooperation is 'immanent in the labouring activity itself'. With immaterial labour, ordered around intellect, communication and affect, the role of the capitalist instead becomes to 'expropriate cooperation' as a means of garnering surplus-value from the self-valorizing activity of workers (Hardt and Negri 2009, p. 141). Indeed, as noted, the World Wide Web itself was a fine example of the incorporation of 'trillions' of hours of free time in a project based upon the innovations and shared collective knowhow of millions of everyday PC users (Ross 2003, p. 218).

Providing the most fully fleshed-out articulation of the new OCC in the autonomist literature, Christian Marazzi posits that the contemporary capitalist organization of production is structured so as to fulfil the primary purpose 
of capturing the value produced in society at large. Bringing together various threads that we have encountered in the autonomist oeuvre thus far, Marazzi suggests that the OCC is still a valid tool for analysing capitalism, albeit recalibrated along strictly immaterial lines. For Marazzi, such 'crowdsourcing' Web 2.0 phenomena as Facebook and Google represent the new OCC. Here constant capital is 'the totality of linguistic machines' that act in society at large to capture what becomes the substance of variable capital, that is 'the totality of sociality, emotions, desires, relational capacity, and...'free labor". 'The 'linguistic machines' that become the new constant capital extend the working day with their acquisitive search for variable capital (Marazzi 2010, p. 56).

The importance of these new forms of constant capital is a corrective to any notion that constant capital has decreased, alleviating the contradiction that sparks the tendency of the rate of profit to fall. Indeed, although Marazzi does point to the reduced costs achieved through the continuing and sometimes infinite usage capacities of these apparatuses of value-capture, we should also consider Marx's distinction between the two departments of the economy: that which produces wage goods, and that which produces the means of production (ibid., p. 59). The constant capital component of the OCC also rises in proportion to the amount of labour expended on producing means of production, for the simple fact that there are more means of production per worker. Virno suggests that we should see the communication industries as a whole as an 'industry of the means of production' adequate to the new forms of constant capital that drive the creation of value (2004, p. 61).

The evidence presented by Ross conforms to this. With the Dot.Com firm he studies primarily operating as a service to other businesses, Ross concludes that '[i]f new media was an industry, it was one that existed to transform other industries '(2003, p. 244). Coupled with the further observation that what pass as wage goods (cellphones, software etc) might also possess a double function as means by which production is extended into the domestic sphere, it is clear that a new context of principally immaterial labour and intangible forms of production resolutely does not discredit the relevancy of constant capital nor a more general sensitivity to the ratio of constant and variable capital presented in the OCC.

Despite the proliferation of constant capital in the ways detailed above, there is also in evidence in the conceptualisations of immaterial labour given in the autonomist tradition the concurrent increase in variable capital by virtue of the expansion of absolute surplus-value through the extension of the working day, as we have seen in the preceding discussion. It is evident that an autonomist-inflected reading and a Marx-inflected reading provide different, but not irreconcilable, understandings of the role of the OCC in determining the economic function of capitalism.

Marazzi (2008, p. 60) claims that the new forms of immaterial production secure an 'economy of increasing returns', working against an underlying fall in the rate of profit. The tendencies described above, the 'putting to work of the language of social relations, the activation of productive cooperation beyond the factory gate' and the extension of the working day are presented therefore as countertendencies to falling profitability, 'respond[ing] to declining profit rates by intensifying the exploitation of the communicative-relational cooperation of the workforce'. In Marxian terms, the rise in profitability is as a result of a return to absolute surplus-value as a means of increasing variable capital in the OCC, restoring the chief input from which capital derives its wealth: labour-time. It is the restatement of labour-time's centrality to the understanding of capitalism that allows autonomist Marxism to continue Marx's work on the topic whilst also endowing it with new characteristics suitable for the era in which we find ourselves.

\section{Conclusion}

We have seen that the autonomists adopt and advance many of Marx's theoretical tools and categories whilst addressing the inability of his quantitative and systematic economic thought to accommodate an immaterial model of production that operates beyond all measure. This is exhibited nowhere more than in the debate over labour-time. Our account of Marx's schematization of labour-time and crisis teased from the research the suggestion that labourtime may possess some determining influence over the rate of profit. Whilst we have displayed that Marx's work holds standalone relevance for the analysis of recent trends in capitalist production, the continuing inquiry of the autonomist Marxists performs the necessary work of dragging Capital kicking and screaming into the uncertainties and absurdities of twenty-first century capitalism. The autonomist theorization of labour-time similarly identifies working hours as possessing a determining influence upon rates of profit, albeit it with a sensitivity to contemporary 
conditions that allows us to see clearly its application in reference to the research of Ross and others on the actual quotidian reality of work in the Dot.Com boom. The combination of conceptual insights from Marx and the autonomists on the subject of labour-time has enabled us to perceive the New Economy and its crisis through a theoretical prism that embraces these everyday conditions of work, whilst simultaneously facilitating extrapolation to a wider economic mise-en-scène capable of interpreting broader macroeconomic claims about the US economy during the nineties and early noughties.

What the meeting of Marx and his autonomist interpreters allows us to comprehend is the way in which the seemingly dislocated logic of the macro-economic picture at times of turbulence such as those of the Dot.Com years can be associated at its very foundations with shifts in the way in which value and wealth are generated in the realm of production. The organisation of time, it has been suggested here, is a key element, both in capitalist responses to crises and at the inception of the economic booms and bubbles that eventuate in these crises. The lesson of Marx, in this sense, is that the way in which time is organised in the workplace is an important aspect which cannot be ignored in analyses of the wider economic picture. However, it is only a lesson, one which needs to be taken forward and fulfilled in the setting of a contemporary suite of conditions in which the organisation of non-work time is as important as the organisation of time in the sphere of formal employment. This difference is central in how we go about approaching the question of labour-time in the Dot.Com bubble and the role it plays in determinations of the organic composition of capital and its attendant impact upon the rate of profit. It is the autonomists that allow us to take Marx's lesson on labour-time and apply to it the specific circumstances which surrounded a New Economy in many ways utterly distinct from the economy Marx had subjected to critical scrutiny, but in very many more important ways still entirely open to interpretation along the lines of the conceptual apparatus provided in Capital and elsewhere. This conceptual apparatus allows us to see that labour-time- in its appearance as variable capital or otherwise- has a bearing upon the successful reproduction of capitalist social relations and those points at which this reproduction can be seen to break down, no matter where, how, when and for how long it is extracted.

\section{Acknowledgments}

The author would like to thank Timothy Cooper at the University of Exeter for his supervision of the 2011 research that eventually resulted in this paper.

\section{Endnotes}

1. Please see Appendix for data sources relevant to this and other graphs presented in this article.

\section{Appendix: Data Sources}

All variables are referenced from the available OECD and Bureau of Economic Analysis indicators, as follows:

Average Working Hours

OECD, 'Average annual hours actually worked per worker', OECD.Stat online database, available at http://
stats.oecd.org/Index.aspx?DataSetCode=ANHRS

[last checked 1st August 2011]

Capital Stock

OECD, 'Capital Stock, total economy, volume', in OECD Economic Outlook available at http://stats. 
oecd.org/Index.aspx?QueryId=29817 [last checked 1st August 2011]

\section{Employee Compensation}

Bureau of Economic Analysis, Table 1.12: National Income by Type of Income, National Income and Product Accounts Tables, National Economic Accounts available at http://www.bea.gov [last checked 1st August 2011]

\section{Net Interest}

Bureau of Economic Analysis, Table 1.16: Sources and Use of Private Enterprise Income, National Income and Product Accounts Tables, National Economic Accounts available at http://www.bea.gov [last checked 1st August 2011]
Non-Financial Corporate Profits

Bureau of Economic Analysis, Non-Financial Corporate Profits with Inventory Valuation and Capital Consumption Adjustment, Table 6.16C and 6.16D: Corporate Profits by Industry, National Income and Product Accounts Tables, National Economic Accounts available at http://www.bea.gov [last checked 1st August 2011]

\section{References}

Brenner, Robert, 1998. "The Economics of Global Turbulence”. New Left Review 229 (special issue)

-.- 2002. The Boom and the Bubble: The US in the World Economy. London: Verso.

---- 2004. "New Boom or New Bubble: The Trajectory of the US Economy”. New Left Review 25, pp. 57-102

Fine, Ben, and Saad-Filho, Alfredo., 2004. Marx's Capital, 4th edn., London: Pluto Press.

Hardt, Michael, 2008. "Introduction". in C. Marazzi, Capital and Language: From the New Economy to the War Economy. Los Angeles: Semiotext(e).pp. 7-11

Hardt, Michael, and Negri, Antonio, 2001. Empire. Cambridge, MA: Harvard University Press.

--- 2004. Multitude: War and Democracy in the Age of Empire. London: Penguin.

---- 2009. Commonwealth. Cambridge, MA: Harvard University Press.

Harvey, David, 2010. A Companion to Marx's Capital. London: Verso.

Marazzi, Christian, 2008. Capital and Language: From the New Economy to the War Economy, trans. by G. Conti. Los Angeles: Semiotext(e).
----2010. The Violence of Financial Capitalism, trans. by K. Lebedeva, Los Angeles: Semiotext(e).

Marx, Karl, 1973. Grundrisse: Foundations of the Critique of Political Economy, trans. by M. Nicolaus, London: Penguin.

-.-- 1981. Capital, Vol. 3. London: Penguin.

---- 1990. Capital, Vol. 1. London: Penguin.

Ross, Andrew, 2003. No-Collar: The Humane Workplace and Its Hidden Costs. New York: Basic Books.

Virno, Paolo, 1996. "The Ambivalence of Disenchantment". trans. M. Turtis, in Radical Thought in Italy: A Potential Politics, ed. by P. Virno and M. Hardt. Minneapolis: University of Minnesota Press. pp. 13-36

-.---2001. "General Intellect" [online], trans. by Arianna Bove, available at www.generation-online.org/p/fpvirno10.htm [accessed 1st January 2012]

-.-- 2004. A Grammar of the Multitude. Los Angeles: Semiotext(e).

Virno, Paolo. and Hardt, Michael (eds.), 1996. Radical Thought in Italy: A Potential Politics. Minneapolis: University of Minnesota Press. 
